\title{
NOVEL RISK MANAGEMENT INTEGRATED MODEL IMPLEMENTATION: COMPARISON BETWEEN MANUFACTURING AND SERVICE COMPANIES
}

\author{
UDC: 005.334 \\ Original Scientific Paper \\ Nuri Mohamed Saad ALHERIANI ${ }^{1}$, Vesna K. SPASOJEVIĆ BRKIĆ ${ }^{2 *}$, \\ Martina B. PERIŠIĆ ${ }^{1}$ \\ ${ }^{1}$ University of Belgrade, Faculty of Mechanical Engineering, Kraljice Marije 16, 11000 Belgrade, \\ Republic of Serbia \\ ${ }^{2}$ University of Belgrade, Faculty of Mechanical Engineering, Kraljice Marije 16, 11000 Belgrade, \\ Republic of Serbia \\ E-mail: vspasojevic@ mas.bg.ac.rs
}

Paper received: 16.01.2021; Paper accepted: 29.03.2021

\begin{abstract}
Till now a framework to define a common and unified standard model for integrated risk management systems, which is suitable to be used in all contingency factors settings, has not been found. For this reason, as the main objective of applying the standards of management systems in the organizations is to determine the risk that affects the ability of the organization to achieve its goals and desired results in addition to organizing and coordinating all operations and the optimal use of resources, the purpose is to develop an integrated risk management model for standardized management systems with growing trends such as ISO 9001:2015, ISO 14001:2015, ISO/IEC 27001:2013, ISO 45001:2018 and ISO 22000:2018 with the aim to allow organizations to manage their operations and risks appearing in a manner that reduces the use of available resources and improves the overall performance. Novel risk management integrated model in standardized management systems has three levels - correspondence, coordination and integration and putting in place a clear and structured approach to control of organizational risk. Proposed model has been checked empirically to survey contextual independence of proposed model using Mann-Whitney $U^{*}$ test and it has been proved that the model is context free and applicable to companies from different sectors - both in production and service companies.
\end{abstract}

Keywords: Risk Management; Context; Sectors.

\section{INTRODUCTION}

Nowadays organizations work in risky, very unstable environments and accordingly they seek to use various management system standards in order to organize their management systems and improve the performance of their operations in the desired way giving appropriate answer to disturbances that appear in internal and external environments (Tomić \& Spasojević-Brkić, 2011). Quality management standards are usually seen as the main driving force to reach competitiveness in global landscape (Tomić et al., 2012) and nowadays even those standards contain risk management as a very important part (Chiarini, 2017; Rybski et al., 2017). Accordingly, risk analysis could be seen as an adequate base for a complex management system capable of reaching desired aims and results. Today, there is a need to provide necessary support to manage and address the risk subjected in processes of providing products and services to clients while providing confidence, safety and security to all stakeholders (Jorgensen et al., 2006; Domingues et al., 2015; Algheriani 2017; Berger \& Gleissner, 2018).

The value and importance of risk management has increased significantly today. One of the most reliable ways to manage organizational risks is to specifically check all processes and ensure that they continue to provide outputs that result in highquality products and services by implementing 
N. M. S. Alheriani Novel risk management integrated model implementation: comparison between

et al. manufacturing and service companies

various standards of management systems (MS) and then integrate them in a manner to reduce cost and time resources simultaneously. From this standpoint, it is aimed to develop a model for managing risk in multiple MS standards (Yilmaz \& Floris, 2010). Additionally, one of the most important clauses in the risk management standard urges organizations to include risk management in all applications and processes and to be an integral part not distinct from other organizational processes, and thus risk management must be integrated into the organization as an important component in policy definition, strategic planning, and influence and consequently change management processes through analyzing the risks, discovering solutions to them, and seize the opportunities in developing every process in the organization (Berger \& Gleissner, 2018).

However, till now a framework has not been found to define a common and unified standard model for integrated management systems that can be used in all contingency factors settings (Savino \& Batbaatar, 2015; Souza \& Alves, 2018). For this reason, as the main objective of applying the standards of management systems in the organizations is to determine the risk that affects the ability of the organization to achieve its goals and desired results in addition to organizing and coordinating all operations and the optimal use of resources, the purpose of this paper was to develop an integrated risk management model for standardized management systems with predicted growing trends: ISO 9001:2015, ISO 14001:2015, ISO/IEC 27001:2013, ISO 45001:2018 and ISO 22000:2018 to allow organizations to manage their operations and risks and to check its contextual dependence in the sense of sector distribution.

\section{METHODOLOGY}

Effective and efficient integration of management systems is extremely important (Zeng et al., 2007). Algheriani, Majstorovic, Kirin and Spasojevic Brkic (2019) Three degrees of integration are depicted, as follows: 1.Correspondence alluding to build the similarity between the principles so as to take care of issues of organization, duplication of work assignments, and disarray between various norms, 2 . Coordination depending on a typical comprehension of conventional procedure and undertaking the executives cycles (Plan-Do-Check-Act) to guarantee the cooperative energies and tradeoffs between the guidelines, and 3. Integration prompting the connection with partners, persistent improvement of the exhibition, superior comprehension of inward and outer difficulties and furthermore a duty culture. The adequacy of each management framework is estimated by the degree of accomplishment of objectives and the reason for everyone in this model is to characterize the board procedure of strategies and explicit framework objectives, risks that influence the accomplishment of objectives and the proper assets and procedures that are expected to satisfy the partners' necessities, needs, and desires. Consequently, setting up the individual management frameworks as indicated by fitting guidelines that are shown in Figure 1 is characterized as follows: ISO 9001:2015 quality MS is used to decide on the essential procedure for transformation of input with product value added, and for treatment of risk nonconformance, as well as identification and realization of quality objectives. Environmental MS is aimed at environmental risk treatment and environmental goals and programs determination and realization according to ISO 14001:2015 standard (Fonseca \& Domingues, 2018). ISO 45001:2018 OH\&S is done for word related wellbeing and security danger anticipation (treatment) just as word related wellbeing and wellbeing objectives and program assurance and acknowledgment (Morgado et al., 2019). ISO/IEC 27001:2018 information security MS is used to treat data security chances, and to decide on their targets and projects. ISO 22000:2018 food safety MS is intended to decide on sanitation dangers treatment just as their targets and HACCP plan (Chen et al., 2018). Companies must spread and build up a strong risk management culture from start to finish in the organizational structure, over all levels of higher representatives and workers, to guarantee management in a vigorous and exhaustive manner over the organization. Notwithstanding consideration of the necessities and desires for all partners, which have identified risks, we likewise consider the commitment and solid initiative of top management and administration to apply the risk-oriented culture.

The PDCA ("plan-do-check-act") cycle is a tool that can be utilized to oversee procedures and frameworks (Labodova, 2004; Rebelo et al., 2016). The procedure approach is another instrument used to deal with a gathering of procedures all together, where the interrelations between them are recognized, and the yields of a past procedure are treated as contributions of the accompanying one so as to guarantee the post-effects of every individual procedure in way to include extra business esteem and to add to accomplishing the last wanted outcomes. 
N. M. S. Alheriani Novel risk management integrated model implementation: comparison between et al.

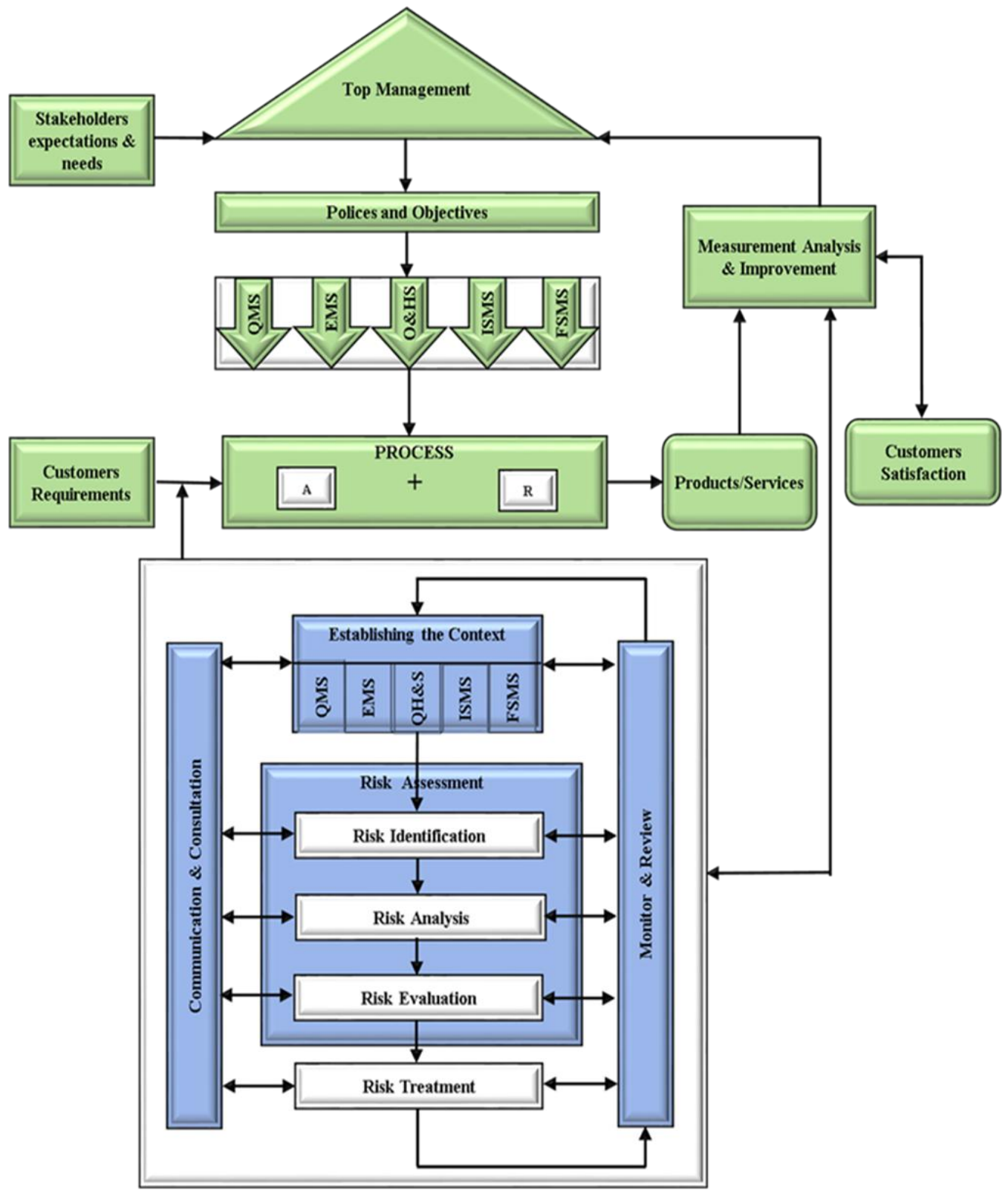

Figure 1: Risk-based IMS model (Algheriani et el., 2019)

These two instruments with chance-based reasoning methodology and hazard the executives are significant components used to fulfil proposed model. Clearly, the executed administration principles in this examination have numerous similarities, as follows: I) in their authoritative structure and procedures through the employments of terms goals, reviews, techniques, records, and so on ii) in their usage paying little heed to type, size or creation, and degree. iii) to standard language utilized and PDCA approach of constant improvement. This comparability in structure, execution, and language utilized with following the PDCA cycle steps can encourage the mix procedure through building up a powerful coordination methodology, as in Algheriani et al.
(2019). The top management plays out an audit and assessment of the coordinated management framework so as to guarantee its ceaseless wellness and productivity in fulfilling the necessities all things considered.

As it is evident, in scientific audience there are no numerous studies connected to integration based on risk principles, with even smaller number of studies on auditing, and since most of the studies are theoretical by substance, it can be concluded that there is a lack of empirical studies. Aimed at this, field study survey has been conducted surveying Serbian companies in order to analyze the integration of risk management practice in the 
N. M. S. Alheriani Novel risk management integrated model implementation: comparison between

et al. manufacturing and service companies

following MSs: ISO 9001, ISO 14001, ISO 45001, ISO 27001, and ISO 22000.

The main objectives of empirical study done are to analyze how organizations in Serbia integrated their MSs and their audits, as well as how they feel and act on risk management issues, all together with difficulties and time needed to integrate MSs, extent of integration of MSs in organizations overall, extent of integrated MS processes, resources and goals, extent of integration of the elements of audit systems and benefits of having integrated audits in organizations together with novel risk model check in practice. The survey contained a cover letter and a questionnaire. The survey used questions with the Likert scale with five levels (scale from 1 to 5), since it is seen as the most commonly used psychometric instrument (Allen \& Seaman, 2007; Maurer \& Pierce, 1998). The survey was posted on Google Docs and its link was sent via email to 200 Serbian companies registered simultaneously in the various management standards. Anyhow, to upgrade the quality of obtained answers, the survey was sent to responsible mangers for managing the standards (their email addresses were used). The survey has covered a number of topics such as important changes in the organization regarding the risk principles, risk mitigation etc.

\section{RESULTS}

At the beginning of 2020, a survey has been launched, containing only descriptive data and the questions given in Table 1. After 3 months, and two reminders, 30 companies answered. The companies from transitional economies, and Serbia among them, have numerous problems with quality of their business and productivity (Bakator et al., 2019) and they are not usually willing to answer questionnaires in high percents (Karapetrovic \& Spasojevic-Brkić, 2014), so the obtained response rate is not surprising. An average value of number of employees in participating companies amounts 276. Companies belong to ten sectors, as given in Figure 2. The largest part of them is in manufacturing sector with $20 \%$, followed by energy and construction sectors with $17 \%$.

Table 1 shows the manner in which the MannWhitney U-test has been used to compare differences between two independent groups, since the dependent variable is either ordinal or continuous, but not normally distributed and results will show if there are significant differences.

The results of survey, which were obtained on a sample in size of 30 Serbian companies, as in Table 1., show that proposed model is not dependent on context regarding industry type, since there were no evidenced significant differences in given answers, which means that the proposed model application independently of contingent factors could be recommended.

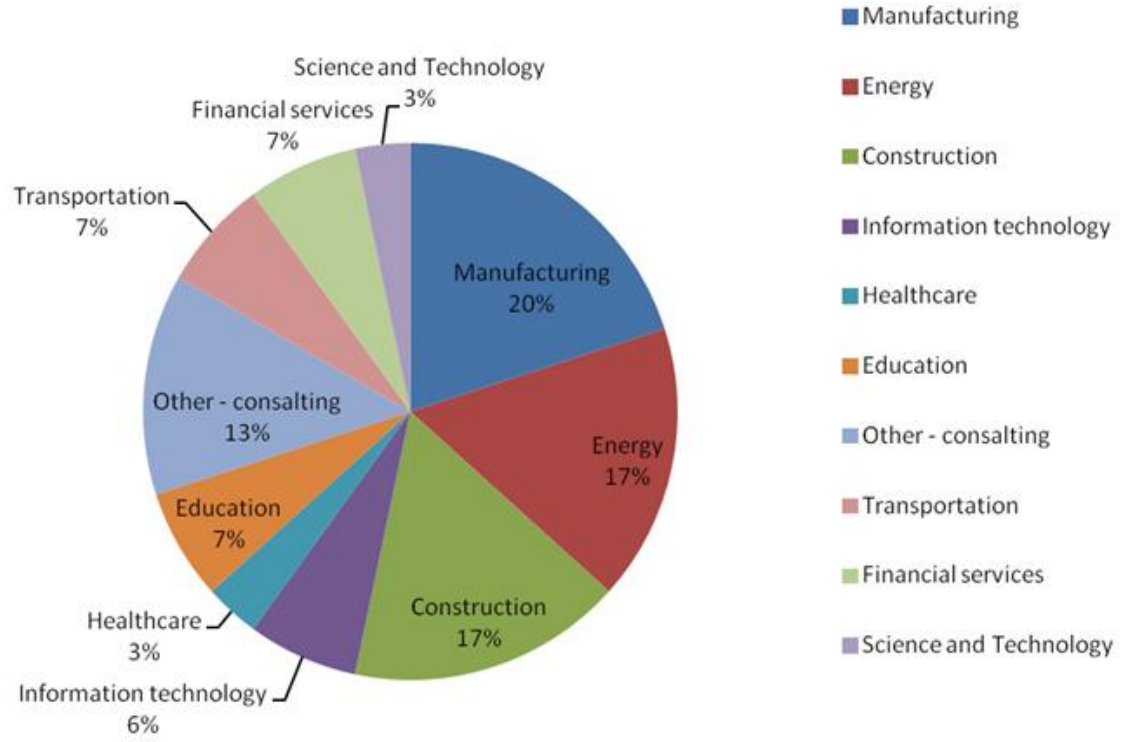

Figure 2: Distribution of the companies in the sample by sectors 
N. M. S. Alheriani Novel risk management integrated model implementation: comparison between

et al.

manufacturing and service companies

Table 1: Comparisons between manufacturing \& construction vs. other service companies attitudes on risk model using Mann-Whitney $U^{*}$ test

\begin{tabular}{|c|c|c|c|}
\hline $\begin{array}{l}\text { Manufacturing \& Construction vs. Service companies } \\
\text { In our organization top management... }\end{array}$ & Z statistic & p-value & Significance \\
\hline $\begin{array}{l}\text {... should establish risk-based policies/objectives to set and follow } \\
\text { the realization of the goals of the standards. }\end{array}$ & -1.123666 & 0.251155 & n.s. \\
\hline $\begin{array}{l}\text {...should establish risk-based policies/objectives that are } \\
\text { appropriate to the purpose and context of the organization } \\
\text { including the nature, scale, and impacts of its activities, products, } \\
\text { and services. }\end{array}$ & -0.666667 & 0.504985 & n.s. \\
\hline $\begin{array}{l}\text {... should establish risk based policies/objectives that include a } \\
\text { commitment to continual improvement of aspects such as quality, } \\
\text { environment, health, and safety....etc. }\end{array}$ & 0.235702 & 0.813664 & n.s. \\
\hline $\begin{array}{l}\text {... should establish risk-based policies/objectives that include a } \\
\text { commitment to legal and legislation requirements. }\end{array}$ & -0.942809 & 0.345779 & n.s. \\
\hline $\begin{array}{l}\text {... should establish policies/objectives that are based on risk } \\
\text { evaluation and opportunities. }\end{array}$ & -0.666667 & 0.504985 & n.s. \\
\hline $\begin{array}{l}\text {... should establish risk-based policies/objectives that include a } \\
\text { commitment to participation, i.e. the involvement of workers and } \\
\text { employees. }\end{array}$ & -0.674200 & 0.500184 & n.s. \\
\hline $\begin{array}{l}\text {... should establish risk-based policies/objectives that reward } \\
\text { employees for the achieved risk management mitigation. }\end{array}$ & -0.449467 & 0.653095 & n.s. \\
\hline $\begin{array}{l}\text {... should plan to identify all the processes and procedures } \\
\text { necessary to address risk in terms of objectives, sequence, input } \\
\text { and output, key performance indicators, and its criteria. }\end{array}$ & -1.854956 & 0.063603 & n.s. \\
\hline $\begin{array}{l}\text {...should plan to identify all the adequate resources to address the } \\
\text { different types of risks }\end{array}$ & -0.463739 & 0.642835 & n.s. \\
\hline $\begin{array}{l}\text {... should plan to determine the risk management processes in } \\
\text { terms of risk identification, risk analysis, risk evaluation, and risk } \\
\text { treatment. }\end{array}$ & -0.449467 & 0.653095 & n.s. \\
\hline $\begin{array}{l}\text {... should clearly define organizational structure, roles, powers and } \\
\text { responsibilities for risk management. }\end{array}$ & -0.228218 & 0.819227 & n.s. \\
\hline $\begin{array}{l}\text {...should provide regularly training related to quality, environment, } \\
\text { health, and safety...etc. to all workers and levels in the } \\
\text { organization. }\end{array}$ & 0.449467 & 0.653095 & n.s. \\
\hline $\begin{array}{l}\text {...should communicate and consult all stakeholders at all stages of } \\
\text { the risk management process. }\end{array}$ & -0.449467 & 0.653095 & n.s. \\
\hline $\begin{array}{l}\text {... should supervise and participate in the identification of risks } \\
\text { with their likelihoods and consequences to calculate the magnitude } \\
\text { of risks. }\end{array}$ & 1.290994 & 0.196706 & n.s. \\
\hline $\begin{array}{l}\text {...should document the results of the monitoring and review of the } \\
\text { risk management process. }\end{array}$ & 0.674200 & 0.500184 & n.s. \\
\hline $\begin{array}{l}\text {... should compare the magnitude of risk to the predefined criteria } \\
\text { in a systematic periodic time. }\end{array}$ & 1.290994 & 0.196706 & n.s. \\
\hline $\begin{array}{l}\text {... should identify and assess options of risks in order to determine } \\
\text { the priorities of risks that need to be treated. }\end{array}$ & -0.235702 & 0.813664 & n.s. \\
\hline ...should implement corrective and preventive actions. & -0.463739 & 0.642835 & n.s. \\
\hline ...should implement internal and external audit program. & -0.235702 & 0.813664 & n.s. \\
\hline $\begin{array}{l}\text {...should implement a management review in a systematic and } \\
\text { periodic time. }\end{array}$ & 1.290994 & 0.196706 & n.s. \\
\hline ...should implement risk treatment for all risks & -0.942809 & 0.345779 & n.s. \\
\hline ...should select the options for risk treatment & 1.573133 & 0.115688 & n.s. \\
\hline ...should prepare and implement risk treatment plans & -0.942809 & 0.345779 & n.s. \\
\hline
\end{tabular}


N. M. S. Alheriani Novel risk management integrated model implementation: comparison between

et al. manufacturing and service companies

\section{CONCLUSION AND IMPLICATIONS}

The school of contingent management as the basic premise has the fact that there is no universal, generally accepted organizational theory, but when designing an organization it is necessary to take into account external and internal factors that affect parts of the organization or the organization as a whole, as later on emphasized in standards (Brkić et al., 2009; Spasojevic Brkic et al., 2013). Namely, the context represents by both internal and external factors could have an impact on the attainment of the goals of the organization, whose tracking enables to identify, evaluate, and manage risk- related to stakeholders and their changing needs and expectations.

According to experimental verification and theoretical enrichment of contextual theory for decades, with the increasing tendency to determine the influence of contingent factors and increasing the complexity of the research with the same objective, the Mann-Whitney U test was used in this survey to compare the differences between manufacturing and service companies in implementing the proposed risk management integrated model and it has been proven that the proposed model is not dependent on context in relation to size and type of industry, which means that it is recommended to apply it independently of contingent/contextual factors.

Recommendation for future research in this area is a more detailed analysis of collected data using more sophisticated statistical analysis tools, such as regression analysis, structural equations modelling and similar to see interrelations between variables in the proposed model and performance indicators. Also, an influence of demographic factors such as companies' size could be checked using the same methodology and Mann-Whitney $\mathrm{U}^{*}$ test.

\section{ACKNOWLEDGEMENT}

The paper is supported by grants from the Ministry of Education, Science and Technological Development, grants from project E!13300 and contract 451-03-68/2020-14/200105 (subproject TR 35017). The authors also thank the respondents who filled out the questionnaires for their kind cooperation.

\section{REFERENCES}

Algheriani, N. M. S. (2017). Business Standardization in the World - State of the Art. International Journal "Advanced Quality", 44(1), 47-52.

Algheriani, N. M. S., Majstorovic, V. D., Kirin, S., \& Spasojevic Brkic, V. (2019). Risk model for integrated management system. Tehnicki Vjesnik, 26(6), 1833-1840. https://doi.org/10.17559/TV20190123142317

Allen, I. E., \& Seaman, C. A. (2007). Likert scales and data analyses. Quality Progress, 40(7), 64-65.

Bakator, M., Đorđević, D., \& Ćoćkalo, D. (2019). Developing a model for improving business and competitiveness of domestic enterprises. Journal of Engineering Management and Competitiveness (JEMC), 9(2), 87-96.

Berger, T., \& Gleissner, W. (2018). Integrated management systems: linking risk management and management control systems. International Journal of Risk Assessment and Management, 21(3), 215231. https://doi.org/10.1504/IJRAM.2018.093751

Brkić, V. S., Klarin, M., \& Ivanović, G. (2009). Influence of contingency factors on the application of quality tools. FME Transactions, 37(3), 143-149.

Chen, H., Liou, B. K., Hsu, K. C., Chen, C. S., \& Chuang, P. T. (2021). Implementation of food safety management systems that meets ISO 22000: 2018 and HACCP: A case study of capsule biotechnology products of chaga mushroom. Journal of Food Science, 86(1), 40-54. https://doi.org/10.1111/17503841.15553

Chiarini, A. (2017). Risk-based thinking according to ISO 9001: 2015 standard and the risk sources European manufacturing SMEs intend to manage. The TQM Journal, 29(2), 310-323. https://doi.org/10.1108/TQM-04-2016-0038

Domingues, J. P. T., Sampaio, P., \& Arezes, P. M. (2015). Analysis of integrated management systems from various perspectives. Total Quality Management \& Business Excellence, 26(11-12), 1311-1334. https://doi.org/10.1080/14783363.2014.931064

Fonseca, L. M., \& Domingues, J. P. (2018). Exploratory research of ISO 14001: 2015 transition among Portuguese organizations. Sustainability, 10(3), 781. https://doi.org/10.3390/su10030781

Jørgensen, T. H., Remmen, A., \& Mellado, M. D. (2006). Integrated management systems - Three different levels of integration. Journal of Cleaner Production, 14(8), 713-722. https://doi.org/10.1016/j.jclepro.2005.04.005

Karapetrovic, S., \& Spasojević-Brkić, V. (2014). Usage of ISO 10000 Augmentative Standards in Serbia. Information Technology, 1(3), 21-23.

Labodová, A. (2004). Implementing integrated management systems using a risk analysis based approach. Journal of Cleaner Production, 12(6), 
N. M. S. Alheriani Novel risk management integrated model implementation: comparison between

et al. manufacturing and service companies

571-580.

https://doi.org/10.1016/j.jclepro.2003.08.008

Maurer, T. J., \& Pierce, H. R. (1998). A comparison of Likert scale and traditional measures of selfefficacy. Journal of Applied Psychology, 83(2), 324. https://doi.org/10.1037/0021-9010.83.2.324

Morgado, L., Silva, F. J. G., \& Fonseca, L. M. (2019). Mapping occupational health and safety management systems in Portugal: outlook for ISO 45001: 2018 adoption. Procedia Manufacturing, 38, 755-764. https://doi.org/10.1016/j.promfg.2020.01.103

Rebelo, M. F., Santos, G., \& Silva, R. (2016). Integration of management systems: Towards a sustained success and development of organizations. Journal of Cleaner Production, 127, 96-111. https://doi.org/10.1016/j.jclepro.2016.04.011

Rybski, C., Jochem, R., \& Homma, L. (2017). Empirical study on status of preparation for ISO 9001: 2015. Total Quality Management \& Business Excellence, 28(9-10), 1076-1089. https://doi.org/10.1080/14783363.2017.1303886

Savino, M. M., \& Batbaatar, E. (2015). Investigating the resources for Integrated Management Systems within resource-based and contingency perspective in manufacturing firms. Journal of Cleaner Production, 104, 392-402. https://doi.org/10.1016/j.jclepro.2015.04.115

Souza, J. P. E., \& Alves, J. M. (2018). Lean-integrated management system: A model for sustainability improvement. Journal of Cleaner Production, 172, 2667-2682.

https://doi.org/10.1016/j.jclepro.2017.11.144

Spasojevic Brkic, V. K., Djurdjevic, T., Dondur, N., Klarin, M. M., \& Tomic, B. (2013). An empirical examination of the impact of quality tools application on business performance: Evidence from Serbia. Total Quality Management \& Business Excellence, 24(5-6), 607-618. https://doi.org/10.1080/14783363.2012.677306

Tomić, B., \& Spasojević-Brkić, V. S. (2011). Effective root cause analysis and corrective action process. Journal of Engineering Management and Competitiveness, 1(1/2), 16-20.

Tomić, B., Spasojević-Brkić, V., \& Klarin, M. (2012). Quality management system for the aerospace industry. Journal of Engineering Management and Competitiveness (JEMC), 2(1), 11-15.

Yilmaz, A. K., \& Flouris, T. (2010). Managing corporate sustainability: Risk management process based perspective. African Journal of Business Management, 4(2), 162-171. https://doi.org/10.5897/AJBM.9000394

Zeng, S. X., Shi, J. J., \& Lou, G. X. (2007). A synergetic model for implementing an integrated management system: an empirical study in China. Journal of Cleaner Production, 15(18), 1760-1767. https://doi.org/10.1016/j.jclepro.2006.03.007

\title{
PRIMENA NOVOG INTEGRISANOG MODELA ZA UPRAVLAJNJE RIZIKOM: POREDJENJE PROIZVODNIH I USLUŽNIH PREDUZEĆA
}

\begin{abstract}
Do sada nije pronađen okvir za definisanje zajedničkog i objedinjenog modela zasnovanog na riziku za integrisane menadžment sisteme koji je pogodan za upotrebu u svim vrstama konteksta. Budući da je glavni cilj primene standarda sistema menadžmenta u organizacijama utvrđivanje rizika koji utiču na sposobnost organizacije da postigne svoje ciljeve i željene rezultate, pored organizovanja i koordinacije svih operacija i optimalnog korišćenja resursa, ciljevi ovog rada su razvoj i provera integrisanog modela upravljanja rizikom za standardizovane sisteme upravljanja sa rastućim trendovima kao što su ISO 9001: 2015, ISO 14001: 2015, ISO / IEC 27001: 2013, ISO 45001: 2018 i ISO 22000: 2018, a u cilju omogućavanja organizacijama da upravljaju svojim poslovanjem i rizicima koji se pojavljuju, na način koji smanjuje upotrebu raspoloživih resursa i poboljšava ukupne performanse. Novi integrisani model upravljanja rizikom u standardizovanim sistemima upravljanja ima tri nivoa - korespondenciju, koordinaciju i integraciju i uspostavlja jasan i strukturiran pristup upravljanju organizacionim rizicima. Predloženi model je empirijski proveren za primenu bez kontekstualne zavisnosti predloženog modela primenom Mann-Whitney U * testa i dokazano je da model nije zavisan od konteksta, tj. primenljiv je u kompanijama iz različitih sektora, kako u proizvodnim, tako i u uslužnim delatnostima.
\end{abstract}

Ključne reči: Menadžment rizikom, Kontekst, Sektor. 